\title{
Pola Pengobatan Insulin dan ACE - Inhibitor pada Pasien Diabetes Melitus Tipe 2 dengan Hipertensi Terhadap Kontrol Glikemik dan Tekanan Darah
}

\section{Murni Mursyid ${ }^{1}$, Chitra Astari ${ }^{2}$}

1,2Program Studi Farmasi, Universitas Muhammadiyah Palopo, Palopo, Indonesia

DOI : https://doi.org/10.29303/sjp.v1i2.32

\section{Article Info}

Received :2020-07-25

Revised :2020-08-26

Accepted:2020-08-27

\begin{abstract}
Abstrak: The research aimed to analyze the insulin and ACE Inhibitor therapy in patients with DM type 2 with hypertension, and giving a profile about the influence on the blood sugar control and blood pressure using the parameter of fasting blood glucose, HbA1C, and blood pressure. The research was conducted in the endocrine clinic of DR. Wahidin Sudirohusodo General Hospital, Makassar, from 2 May through 12 July, 2016. The research was a Cross-Sectional study with the samples chosen using the evhaustive sampling technique. The types of insulin and antihypertension class ACE inhibitor was revealed by the interviews with the patients. The therapy effects of pre and post interventions were analyzed using the parameter of glycaemia, and $\mathrm{HbA1C}$ using the pair sample T-test and blood pressure using Wilcoxon test. The research results indicated that the level of blood sugar after fasting was reduced to 64.08 and the level of $\mathrm{HbA1C}$ was reduced to 1.51 with the value of $P=0.000$. The parameter of systolic and diastolic blood pressures had equal degradation of 12.56 and 12.32 respectively with value of $P=0.000$, meaning $P<0.05$ in statistics.
\end{abstract}

Keywords: DM Type 2 with hypertension, Insulin, ACE Inhibitor, Glycemic Control, Blood Pressure.

Citation: $\quad$ Mursyid, M., Astari, C. (2020). Pola Pengobatan Insulin dan Ace - Inhibitor Pada Pasien Diabetes Melitus Tipe 2 Dengan Hipertensi Terhadap Kontrol Glikemik dan Tekanan Darah. Sasambo Journal of Pharmacy, 1(2), 34-40. doi: https:// doi.org/10.29303/sjp.v1i2.32

\section{Pendahuluan}

Diabetes melitus (DM) adalah suatu kelompok penyakit metabolik dengan karakteristik hiperglikemia yang terjadi karena kelainan sekresi insulin, kerja insulin, atau keduanya (American Diabetes Association, 2015). Diabetes melitus juga merupakan suatu penyakit kronis yang terjadi apabila pankreas tidak dapat menghasilkan insulin yang mencukupi atau tubuh tidak dapat memanfaatkan insulin yang dihasilkan oleh pankreas secara efektif. Hal ini menyebabkan terjadinya peningkatan konsentrasi glukosa di dalam darah yang disebut hiperglikemia (Sweetman, 2009).

Hipertensi adalah suatu keadaan dimana seseorang mengalami peningkatan tekanan darah di atas normal, yaitu melebihi 140/90 mmHg. Ini didasarkan pada dua fase dalam setiap denyut jantung yaitu fase sistolik 140 menunjukkan fase darah yang sedang dipompa oleh jantung dan fase diastolic 90 menunjukkan fase darah yang kembali ke jantung (Triyanto, 2014). Batas tekanan darah yang masih dianggap normal adalah $<130 / 85 \mathrm{mmHg}$, sedangkan bila > 140/90 mmHg dinyatakan sebagai hipertensi, dan diantara nilai tersebut disebut sebagai normaltinggi (World Health Organization, 2011).

Diabetes dan hipertensi merupakan dua kondisi yang diistilahkan sebagai "teman dekat yang buruk" dalam mencetuskan risiko penyakit kardiovaskular. DM dapat meningkatkan risiko penyakit kardiovaskular sebanyak 2-4 kali lipat, sementara hipertensi dapat menyebabkan risiko 
penyakit koroner, serta diperparah dengan stroke. Hubungan yang erat antara kondisi tersebut dengan penyakit mikrovaskular juga ditemukan. Sekitar 50\% pasien DM tipe 2 adalah pasien hipertensi atau sedang menjalani terapi antihipertensi ketika diagnosis ditegakkan. Dalam sebuah penelitian yang dilakukan secara cross-sectional, terdapat sekitar $75 \%$ pasien dewasa DM yang juga menderita hipertensi, yang angkanya dapat meningkat menjadi $80 \%$ jika pasien tersebut mengalami mikroalbuminuria, dan lebih dari $90 \%$ jika pasien mengalami nefropati klinis (Harvey \& Champe, 2016). Berdasarkan hasil penelitian yang dilakukan di RSUP Prof. DR. Kandou Manado, komplikasi berupa hipertensi paling banyak ditemukan pada pasien penderita Diabetes Melitus tipe 2 yang berjumlah 18 pasien atau sebesar 58,1\% (Hongdiyanto dkk., 2014).

Menurut suatu hasil meta-analisis yang dilakukan oleh Herman (2013), ACE inhibitor merupakan terapi pilihan untuk pasien dewasa dengan DM. Sekitar 70 studi acak yang mengevaluasi 11 regimen antihipertensi pada sekitar 37.000 pasien dewasa DM yang Outcome nya meliputi mortalitas, penyakit ginjal stadium akhir, dan peningkatan dua kali lipat kreatinin serum, menunjukkan bahwa ACE inhibitor secara konsisten menunjukkan kemungkinan yang lebih tinggi berada pada posisi teratas.

Permasalahan dalam farmasi klinik terutama muncul karena pemakaian obat untuk pasien yang membutuhkan terapi jangka panjang. Pendalaman terhadap penggunaan obat sangat penting karena DM dan hipertensi merupakan penyakit kronik yang membutuhkan terapi obat secara kontinyu dan pengaturan pola hidup penderita untuk mencegah terjadinya komplikasi. Banyaknya golongan antidiabetik dan antihipertensi yang mempunyai mekanisme kerja, efektifitas dan efek samping yang berbeda menjadi tantangan bagi farmasis untuk memberikan informasi secara jelas dan menyeluruh secara individual dalam rangka meningkatkan keberhasilan pengobatan dan meminimalkan efek samping yang terjadi (Murdiana, 2007).

Konsep penggunaan obat yang rasional dalam beberapa tahun belakangan telah menjadi topik perbincangan dalam berbagai pertemuan tingkat nasional maupun internasional. Berbagai penelitian mengenai keamanan dan keefektifan penggunaan obat yang dilakukan di berbagai negara menunjukkan bahwa penggunaan obat yang tidak rasional merupakan fenomena global. Penggunaan obat yang rasional mengharuskan pasien menerima pengobatan sesuai dengan kebutuhan klinis, dalam dosis yang diperlukan tiap individu dalam kurun waktu tertentu dengan biaya yang paling rendah (WHO, 2011). Penggunaan obat yang rasional harus memenuhi beberapa kriteria, diantaranya tepat cara pemberian, tepat interval pemberian, dan waspada terhadap efek samping (Kementerian Kesehatan Republik Indonesia, 2011).

Penelitian ini bertujuan untuk menganalisis penggunaan kombinasi terapi insulin dan ACE Inhibitor terhadap pasien DM Tipe 2 dengan hipertensi, yang memenuhi kriteria tepat cara pemberian, tepat interval pemberian, dan waspada efek samping berupa hipoglikemia karena adanya interaksi obat dan memberikan gambaran tentang pengaruh terapi kombinasi insulin dan ACE Inhibitor terhadap kontrol gula darah dan tekanan darah pada pasien DM Tipe 2 dengan hipertensi, menggunakan parameter glukosa darah puasa, $\mathrm{HbA1C}$, dan tekanan darah.

\section{Metode}

\section{Rancangan Penelitian dan Lokasi Penelituan}

Penelitian ini merupakan studi Cross Sectional dengan teknik pengambilan sampel secara evhaustive sampling, yang dilaksanakan di poliklinik endokrin Rumah Sakit Umum Pendidikan DR. Wahidin Sudirohusodo Makassar.

\section{Bahan dan Instrumen Pengumpul Data}

Bahan dan instrumen dalam pengumpulan data pada penelitian ini menggunakan data rekam medik, data hasil laboratorium dan hasil wawancara langsung terhadap pasien atau keluarga pasien. Sumber data berupa rekam medik pasien yang menjalani terapi obat insulin dan antihipertensi golongan ACE inhibitor, meliputi data pasien, seperti usia, jenis kelamin, umur, berat badan, tinggi badan, riwayat alergi obat, tindakan terapi terhadap penyakit DM tipe 2 dengan hipertensi, pemeriksaan fisik, pemeriksaan penunjang, dan lain-lain. Sumber data berdasarkan wawancara langsung kepada pasien atau keluarga pasien meliputi aktivitas fisik sehari - hari, pola makan selama menjalani pengobatan, efek samping yang dialami pasien selama mengkonsumsi obat tersebut, kepatuhan kelompok sampel dalam mengkonsumsi obat, cara penggunaan obat, waktu pemberian, dan interval waktu pemberian antara obat satu dengan obat lainnya.

Bahan dan alat ini digunakan untuk menganalisis pola terapi insulin dan ACE Inhibitor pada pasien DM tipe 2 dengan hipertensi di poliklinik endokrin Rumah Sakit Wahidin Sudirohusodo dengan parameter gula darah puasa, HbA1C dan tekanan darah pasien selama kelompok sampel mengkonsumsi obat tersebut.

\section{Populasi dan Sampel}

Populasi dalam penelitian ini adalah semua pasien yang terdiagnosa DM Tipe 2 dengan hipertensi 
di RSUP DR. Wahidin Sudirohusodo yang diberikan terapi insulin dan ACE Inhibitor. Sampel dalam penelitian ini adalah pasien yang terdiagnosa DM Tipe 2 dengan hipertensi di RSUP DR. Wahidin Sudirohusodo yang diberikan terapi insulin dan ACE Inhibitor yang sesuai dengan kriteria inklusi dan kriteria eksklusi. Besar sampel ditentukan dengan metode exhaustive sampel (sampel jenuh). Cara penarikan sampel seperti ini sering dianggap sebagai total sampel, dimana semua anggota populasi dimasukkan sebagai sampel. Metode ini dilakukan bila jumlah populasi relative kecil, kurang sari 30 orang (Buraerah, 2013).

Adapun kriteria inklusi dalam penelitian ini adalah (1) Pasien didiagnosa DM tipe 2 dengan hipertensi (2) Pasien mendapatkan terapi insulin dan ACE Inhibitor (3) Pasien dengan kadar HbA1c > 7\% (4) Pasien dengan tekanan darah sistolik $\geq 140 \mathrm{mmHg}$ dan tekanan darah diastolic $\geq 90 \mathrm{mmHg}$.

\section{Analisis dan Penyajian Data}

Analisa data dilakukan dengan program SPSS 21 dan uji statistik untuk perbedaan tekanan darah sampel pre dan post intervensi menggunanakan uji wilcoxon, sedangkan untuk data penurunan kadar gula darah puasa dan kadar HbA1C menggunakan Uji T Sampel berpasangan.

\section{Hasil dan Pembahasan}

\section{Karakteristik Sampel}

Tabel 1 menunjukkan bahwa subyek penelitian ini lebih banyak pria dibandingkan wanita dan frekuensi tertinggi pada kelompok umur 51-60 tahun (umur $>40$ tahun) yaitu sebanyak 24 orang $(96 \%)$. Hal ini sesuai dengan teori yang menyatakan bahwa kejadian DM dipengaruhi juga oleh faktor umur, dimana umur $>40$ tahun rentan terkena DM tipe 2 karena terjadinya intoleransi yang disebabkan oleh faktor degenartif yaitu menurunnya fungsi tubuh, khususnya kemampuan sel $\beta$ dalam memproduksi insulin untuk memetabolisme glukosa.

Tabel 1. Karakteristik demografi berdasarkan Jenis Kelamin dan umur subyek penelitian.

\begin{tabular}{lcc}
\hline Karakteristik Sampel & \multicolumn{2}{c}{ Kelompok } \\
& $\mathbf{n}(\mathbf{2 5})$ & $\%$ \\
\hline JenisKelamin & 20 & 80.0 \\
Pria & 5 & 20.0 \\
Wanita & & \\
\hline Umur & 1 & 4.0 \\
30-40 tahun & 6 & 24.0 \\
51-60 tahun & 10 & 40.0 \\
$61-70$ tahun & 7 & 28.0 \\
$71-80$ tahun & 1 & 4.0 \\
\hline
\end{tabular}

\section{Analisis Terapi dan jenis Obat}

Tabel 2 menunjukkan bahwa untuk terapi insulin, frekuensi penggunaan terapi kombinasi lebih tinggi, yaitu 20 orang $(80 \%)$ dibandingkan dengan terapi tunggal, yaitu 5 orang (20\%). Pilihan jenis insulin untuk terapi tunggal, hampir sama frekuensinya antara Novorapid, Novomix, dan Lantus. Sedangkan jenis Insulin untuk terapi kombinasi semua sampel menggunakan kombinasi Novorapid denganLevemir. Sementara untuk terapi ACE inhibitor, frekuensi penggunaan terapi tunggal hampir sama dengan terapi kombinasi, yaitu 13 orang (52\%) sementara terapi kombinasi sebanyak 12 orang (48\%). Pilihan jenis untuk terapi tunggal ACE Inhibitor yang tertinggi adalah captopril, $12,5 \mathrm{mg}$ sebanyak 5 orang $(20 \%)$ dan Ramipril $2.5 \mathrm{mg}$, yaitu 4 orang (16\%). Pilihan terapi dengan frekuensi tertinggi untuk kombinasi ACE inhibitor dengan 2 jenis obat adalah Ramipril $2.5 \mathrm{mg}$ dan Bisoprolol 2,5 mg yaitu 4 orang (26\%) sementara ACE inhibitor dengan kombinasi 3 obat memiliki frekuensi yang sama.

Tabel 2. Gambaran Terapi dan Jenis Obat

\begin{tabular}{|c|c|c|c|}
\hline \multirow{2}{*}{ Terapi } & \multirow{2}{*}{ JenisObat } & \multicolumn{2}{|c|}{ Frekuensi } \\
\hline & & n (25) & $\%$ \\
\hline \multicolumn{4}{|l|}{ Insulin } \\
\hline \multirow[t]{4}{*}{ Tunggal } & Novorapid & 1 & 4 \\
\hline & Novomix & 2 & 8 \\
\hline & Lantus & 2 & 8 \\
\hline & Total & 5 & 20 \\
\hline \multirow[t]{3}{*}{ Kombinasi } & Novorapid & & \\
\hline & Levemir & 20 & 80 \\
\hline & Total & 20 & 80 \\
\hline \multicolumn{4}{|l|}{ ACE Inhibitor } \\
\hline \multirow[t]{5}{*}{ Tunggal } & Ramipril $2.5 \mathrm{mg}$ & 4 & 16 \\
\hline & Ramipril $10 \mathrm{mg}$ & 1 & 4 \\
\hline & Lisinopril $5 \mathrm{mg}$ & 2 & 8 \\
\hline & Captopril 12,5mg & 5 & 20 \\
\hline & Total & 12 & 48 \\
\hline \multirow[t]{17}{*}{ Kombinasi } & Ramipril 5 mg & & \\
\hline & Dialtiazem & 1 & 4 \\
\hline & $200 \mathrm{mg}$ & & \\
\hline & $\begin{array}{l}\text { Ramipril } 5 \mathrm{mg} \\
\text { Amlodipin } 10 \mathrm{mg}\end{array}$ & 1 & 4 \\
\hline & $\begin{array}{l}\text { Ramipril } 2.5 \mathrm{mg} \\
\text { Bisoprolol } 2,5 \mathrm{mg}\end{array}$ & 4 & 16 \\
\hline & Captopril $12,5 \mathrm{mg}$ & & \\
\hline & Furosemid $40 \mathrm{mg}$ & 3 & 12 \\
\hline & Lisinopril $10 \mathrm{mg}$ & 1 & 4 \\
\hline & Bisoprolol $5 \mathrm{mg}$ & & \\
\hline & Total & 10 & 40 \\
\hline & Ramipril 5 mg & & \\
\hline & Furosemid $40 \mathrm{mg}$ & 1 & 4 \\
\hline & Bisoprolol 2,5mg & & \\
\hline & Lisinopril $10 \mathrm{mg}$ & & \\
\hline & Valsartan $80 \mathrm{mg}$ & 1 & 4 \\
\hline & Furosemid $40 \mathrm{mg}$ & & \\
\hline & Total & 3 & 12 \\
\hline
\end{tabular}


Analisis Ketepatan cara pemberian, interval waktu pemberian, interaksi obat dan efek samping berupa hipoglikemia

Tabel 3 menunjukkan bahwa subyek penelitian yang kurang tepat dalam penggunaan terapi sebesar 8 orang (32\%), frekuensinya lebih rendah dibandingkan dengan yang tepat dalam penggunaan terapi, yaitu 17 orang (68\%). Dari aspek interval waktu pemberian, hasil menunjukkan bahwa semua subyek (25 orang, $100 \%$ ) memiliki interval yang baik . Hasil juga menunjukkan bahwa tidak ada subyek yang mengalami interaksi obat dan efek samping terapi berupa hipoglikemia.

Tabel 3. Gambaran Ketepatan Cara, Interval Pemberian, Interaksi dan Efek Samping Terapi

\begin{tabular}{lcc}
\hline Parameter & \multicolumn{2}{c}{ Frekuensi } \\
& n(25) & \% \\
\hline Ketepatan cara pemberian & 17 & 68 \\
Tepat & 8 & 32 \\
KurangTepat & & \\
Interval waktu pemberian & 25 & 100 \\
Baik & 0 & 0 \\
Kurang & & \\
InteraksiObat dengan & & \\
Insulin dan ACEI & 0 & 0 \\
$\quad$ Ada & 25 & 100 \\
Tidak ada & & \\
Efek Samping & & \\
(hipoglikemia) & 0 & 0 \\
Ada & 25 & 100 \\
Tidak ada & & \\
\hline
\end{tabular}

\section{Analisis Efek Terapi Terhadap Tekanan Darah, Kadar} Gula Darah Puasa dan HbA1C

Analisis efek terapi terhadap tekanan darah, kadar gula darah puasa dan HbA1C dilakukan dengan membandingkan antara kondisi sebelum intervensi (pre) dengan setelah intervensi (post). Uji statistic yang digunakan adalah uji beda baik parametrik (uji $\mathrm{T}$ sampel berpasangan) maupun non parametrik (Uji Wilcoxon) untuk data yang tidak berdistribusi normal. Nilai signifikansi yang digunakan untuk menilai perbedaan rerata tekanan darah, kadar gula darah puasa dan kadar $\mathrm{HbA1C}$ adalah $5 \%$.

Tabel 4 Memperlihatkan hasil tekanan darah yang dianalisis dengan uji statistic uji Wilcoxon dimana tekanan darah sistol turun secara signifikan setelah terapi kurang lebih 3 bulan, yaitu sebesar 12.56 $\mathrm{mgHg}$ dan penurunan tekanan darah ini signifikan secara statistik $(p=0.000, p<0.05)$. Tekanan darah diastole juga turun secara signifikan $(p=0.000, p<0.05)$ sebesar $12.32 \mathrm{mmHg}$.

Kadar gula darah puasa yang di analisis dengan uji $\mathrm{T}$ sampel berpasangan setelah terapi 3 bulan mengalami penurunan sebesar $64.08 \mathrm{mg} / \mathrm{dl}$ dan penurunan ini signifikan secara statistic $(p=0.000$, $\mathrm{p}<0.05)$. Kadar HbA1C yang juga dianalisis dengan uji $\mathrm{T}$ sampel berpasangan setelah terapi 3 bulan juga mengalami penurunan sebesar $1.51 \%$ dan penurunan ini signifikan secara statistik $(p=0.000, p<0.05)$.

Tabel 4. Perbedaan Tekanan Darah, Kadar Gula Darah Puasa dan HbA1C Pre dan Post Intervensi

\begin{tabular}{lrcrc}
\hline \multirow{2}{*}{ Paramater } & Pre Terapi & Post Terapi & Beda & Rerata \\
\cline { 2 - 3 } & Rerata \pm SD & Rerata \pm SD & P \\
\hline $\begin{array}{l}\text { Tekanan Darah } \\
\begin{array}{l}\text { Sistol } \\
(\mathrm{mmHg})\end{array}\end{array}$ & $146.04 \pm 20.21$ & $133.48 \pm 19.89$ & -12.56 & $0.000^{*}$ \\
& & & &
\end{tabular}

Tekanan Darah

Diastol $(\mathrm{mmHg}) \quad 89.88 \pm 20.37 \quad 77.56 \pm 10.05 \quad-12.32 \quad 0.000^{*}$

$\begin{array}{lllll}\text { Gula Darah } \quad 231.08 \pm 107.88 & 167.00 \pm 70.37 & -64.08 & 0.000^{* *}\end{array}$

Puasa

$(\mathrm{mg} / \mathrm{dl})$

HbA1c (\%) $\quad 10.22 \pm 1.78 \quad 8.71 \pm 1.49 \quad-1.51 \quad 0.000^{* *}$

*Uji Wilcoxon

**Uji T SampelBerpasangan

- Rerata Turun

+Rerata Naik

Berdasarkan hasil penelitian, peneliti mampu menjawab hipotesa dari penelitian ini, yaitu pemberian terapi kombinasi insulin dan ACE Inhibitor rasional dan memberikan efek yang baik terhadap kontrol gula darah dan tekanan darah pada pasien DM tipe 2 dengan hipertensi, dan terapi kombinasi insulin dan ACE Inhibitor tidak saling berinteraksi jika diberikan dengan interval waktu yang sesuai.

Berdasarkan hasil penelitian yang dilakukan terhadap 25 orang subyek penelitian yang terdiagnosa DM tipe 2 dengan hipertensi yang mendapatkan terapi insulin dan antihipertensi golongan ACE Inhibitor menggunakan parameter glukosa darah puasa, HbA1C, dan tekanan darah diperoleh data bahwa perbedaan hasil gula darah puasa, HbA1C, dan tekanan darah pre dan post intervensi yang di follow up selama masa penelitian mengalami penurunan yang bermakna secara statistic.

Adapun hasil penelitian yang memenuhi kriteria tepat cara pemberian, tepat interval pemberian, interaksi obat dan efek samping berupa hipoglikemia yaitu bahwa sebagian besar pasien sudah tepat cara pemberian obatnya. Ketepatan cara pemberian obat terlihat bahwa pasien menggunakan obat insulin sesaat sebelum makan sudah tepat seratus persen dan untuk insulin glargine dan detemir digunakan malam sebelum tidur dan dilakukan secara rutin dan konsisten pada waktu yang sama setiap hari. Untuk 
penggunaan obat antihipertensi golongan ACE inhibitor tidak tepat sebanyak 8 orang, dimana pasien tersebut menggunakan obat captopril. Captopril seharusnya dikonsumsi pada saat lambung kosong, misalnya 1 jam sebelum makan atau 1-2 jam setelah makan, namun pasien mengkonsumsi captopril sesaat setelah makan atau kurang lebih setengah jam setelah makan. Dalam hal ini terjadi interaksi farmakokinetik antara captopril dengan makanan pada fase absorbsi. Dimana interaksi antara captopril dengan makanan dapat menurunkan absobsi captopril sehingga direkomendasikan meminum obat pada saat perut kosong atau secara konsisten pada waktu yang sama setiap hari (Mozayani \& Raymon, 2014). Absorbsi kaptopril berkurang sebesar 30 - 40\% jika diberikan bersamaan dengan makanan (Sukandar dkk., 2013).

Penggunaan jenis insulin yang paling banyak digunakan adalah kombinasi insulin Novorapid (insulin aspart) bersifat rapid acting dan levemir (insulin detemir) bersifat long acting sebanyak 20 orang $(80 \%)$. Insulin aspart bersifat rapid acting (kerja cepat dan kerja singkat), onset atau mulai kerja dalam 30 menit dan mencapai puncak $1-3$ jam dengan durasi kerja 7-8 jam (Tjay \& Rahardja, 2010).

Berdasarkan hasil penelitian pasien diberikan insulin diwaktu pagi, siang, dan malam dengan interval waktu 6 jam, yaitu pukul 07.00 pagi, 13.00 siang, dan malam pukul 19.00 dan disuntikkan sebelum makan. Hal ini sudah sesuai penggunaannya berdasarkan literatur. Penggunaan insulin aspart pada pasien DM tipe dengan hipertensi, ada yang diberikan secara tunggal dan adapula yang kombinasi. Untuk pasien yang diberikan insulin aspart secara tunggal, berdasarkan hasil penelitian dapat digambarkan bahwa interval waktu pemberiannya sudah tepat, dan pasien melakukan terapi secara konsisten pada waktu yang sama setiap hari. Pada pemberian kombinasi dengan insulin detemir yang bersifat long acting , pasien juga telah melakukannya dengan tepat, yakni disuntikkan secara sub kutan pada malam hari pukul 22.00 menjelang tidur, dan dilakukan secara konsisten pada waktu yang sama setiap hari. Sediaan insulin kerja panjang yang digunakan dalam penelitian ini adalah Insulin glargine dan detemir. Interval waktu pemberian insulin aspart dan detemir pada malam hari yakni pada pukul 19.00 dan 22.00 yaitu 3 jam sudah tepat karena insulin aspart memiliki onset 30 menit dan mencapai puncak 1-3 jam, setelah itu dilanjutkan pemberian insulin detemir dengan interval waktu 3 jam sehingga dianggap dapat memelihara kondisi gula darah yang terkontrol pada waktu tidur malam.

Pasien yang mendapatkan insulin secara tunggal yaitu sebanyak 5 orang pada penelitian ini diperoleh data bahwa interval waktu pemberiannya sudah tepat dan sesuai dengan literature. Jenis insulin yang diberikan meliputi jenis insulin aspart yang bersifat short acting sebanyak 1 orang, dimana interval waktu pemberian insulinnya selama 7 jam. Insulin campuran yang bersifat medium acting sebanyak 2 orang, interval waktu pemberian insulinnya selama 12 jam dan insulin glargine yang bersifat long acting sebanyak 2 orang dengan interval waktu pemberian insulinnya selama 24 jam. Adapun interval waktu pemberian insulin dan antihipertensi golongan ACE Inhibitor berdasarkan hasil penelitian dikatakan sudah tepat karena tidak diberikan secara bersamaan, melainkan dengan interval waktu kurang lebih 30 menit pada sebagian besar subyek penelitian. Hal ini sesuai dengan suatu penelitian yang mengatakan bahwa mekanisme interaksi yang terjadi antara insulin dan golongan ACE inhibitor (kaptopril) yaitu menyebabkan peningkatan sensitifitas insulin sehingga dapat menyebabkan terjadinya hipoglikemia, namun disisi lain aktivitas obat golongan ACE inhibitor dapat melindungi ginjal sehingga akan mengurangi terjadinya nefropati diabetic. Oleh karena alasan itu, obat golongan ACE inhibitor masih dipertahankan dan digunakan secara klinik pada pengobatan hipertensi dengan DM tipe 2 (Mayasari dkk., 2015).

Manajemen pemberian terapi kombinasi tersebut yaitu dengan pengaturan dosis obat yang diberikan sesuai kebutuhan pasien serta pengaturan waktu pemberian obat dan yang paling penting dilakukan monitoring untuk melihat hasil terapi pada pasien tersebut (Stockley, 2006).

Berdasarkan literatur diketahui bahwa penggunaan insulin dan antihipertensi golongan ACE Inhibitor secara bersamaan dapat menyebabkan terjadinya interaksi obat dimana efek hipoglikemik dari insulin semakin meningkat. Interaksi ini dapat meningkatkan pula kejadian efek samping berupa hipoglikemia jika tidak diberikan secara hati-hati dengan memperhatikan ketepatan cara pemberian dan interval waktu pemberian untuk masing-masing obat. Reaksi hipoglikemia merupakan komplikasi yang paling lazim terjadi pada terapi insulin. Reaksi tersebut diduga berasal dari penundaan/keterlambatan makan, latihan/aktifitas fisik yang berlebihan, atau suatu dosis insulin yang terlalu besar untuk penggunaan segera dan adanya interaksi insulin dengan obat lain yang mempengaruhi kerja insulin. Pada penelitian ini, dapat dikatakan bahwa terjadinya interaksi obat seperti yang dimaksud pada penjelasan diatas tidak terjadi karena pasien tidak menggunakan insulin dan antihipertensi golongan ACE Inhibitor secara bersamaan, melainkan dengan interval waktu kurang lebih 30 menit. Suatu penelitian yang dilakukan di RSU Bhakti Wira Tamtama Semarang, menyatakan bahwa distribusi penggunaan obat penyerta pada pasien DM adalah 
obat antihipertensi golongan ACE Inhibitor khususnya kaptopril, yaitu sebesar 39,13\% (Arifin dkk., 2006).

Berdasarkan hasil penelitian dengan wawancara langsung kepada pasien, dikatakan bahwa pasien tidak mengalami hipoglikemia karena telah melakukan cara pemberian obat yang tepat dan memperhatikan interval waktu pemberian obat yang tepat pula. Selain itu, pasien juga sudah mampu melakukan Pemantauan Glukosa Darah Mandiri (PDGM) yang dianjurkan oleh dokter ketika pasien mendapatkan terapi insulin yang ditujukan juga untuk penyesuaian dosis dan memantau timbulnya hipoglikemia (Perkeni, 2011).

Berdasarkan suatu penelitian yang dilakukan di RSU Karanganyar oleh Mutmainnah (2013), menyatakan bahwa terdapat hubungan antara kadar gula darah dan tekanan darah pada pasien DM. Oleh karena itu, kontrol glikemik merupakan hal yang penting dan merupakan sasaran terapi, namun tindakan terapi lain juga harus diambil termasuk kontrol tekanan darah. Berdasarkan data eksperimental dan data epidemiologi. menunjukkan bahwa aktivasi renin-angiotensin-aldosteron berperan penting dalam meningkatkan komplikasi mikrovaskuler dan makrovaskuler pada pasien DM. ACE inhibitor tak hanya sebagai antihipertensi yang poten, tetapi juga menunujukkan efek protektif terhadap organ spesifik, seperti ginjal, jantung, dan mata serta saraf perifer pada pasien DM dengan hipertensi. Efek ini merupakan hasil penghambatan efek hemodinamik dan jaringan dari angiotensin II. Menurut suatu studi kohort yang dipublikasikan dalam jurnal Diabetes Care 2004, ACE inhibitor secara bermakna menurunkan mortalitas akibat semua penyebab pada pasien dengan DM tipe 2 yang tidak mempunyai riwayat penyakit kardiovaskuler. Dibandingkan dengan kontrol yang tidak mendapat ACE inhibitor, lebih sedikit kematian pada kelompok ACE inhibitor (17,1\% dibanding 8,6\%. Kematian dari penyebab kardiovaskuler juga menurun pada kelompok ACE inhibitor, yaitu 3,4\% dibandingkan 5,2\% (Barclay \&Vega, 2004).

\section{Simpulan}

Penelitian ini menyimpulkan terjadi perbedaan bermakna pada penurunan gula darah dan tekanan darah pasien DM Tipe 2 dengan hipertensi yang mendapatkan terapi insulin dan ACE Inhibitor . Kombinasi terapi ini sangat besar manfaatnya, karena penggunaan ACE Inhibitor dapat menurunkan tekanan darah dan juga meningkatkan sensitivitas insulin, meskipun penggunaan secara bersamaan dapat saling berinteraksi dan meningkatkan risiko efek samping berupa hipoglikemia, namun efek tak diinginkan tersebut dapat diatasi dengan memperhatikan ketepatan cara pemberian dan interval waktu pemberian obat.

\section{References}

American Diabetes Association. (2015). Standard Of Medical Care In Diabetes Mellitus. Diabetes Care.

Arifin, Prasetyaningrum, \& Andayani. (2006). Evaluasi Kerasionalan Pengobatan Diabetes Melitus Tipe 2 pada Pasien Rawat Inap di Rumah Sakit Bhakti Tamtama Semarang Tahun 2006.

Barclay \& Vega. (2004). ACE Inhibitors Improve Survival in Type 2 Diabetes. Diabetes Care, 27: 1330-4.

Buraerah. (2013). Analisis Deskriptif Data Riset kesehatan. Makassar: Masagena Press.

Harvey A. \& Champe C. (2016). Farmakologi Ulasan Bergambar, Edisi 4. Jakarta: EGC.

Herman. (2013). Meta-analysis Finds ACE Inhibitors Superior in patients with Diabetes. NEJM Journal Watch.

Hongdiyanto, Yamlean, \& Supriati S. (2014). Evaluasi Kerasionalan Pengobatan Diabetes Melitus Tipe 2 Pada Pasien Rawat Inap Di RSUP Prof.DR.RD. Kandou Manado. Pharmacon, Jurnal Ilmiah Farmasi - UNSRAT Vol. 3 No. 2 Mei.

Kementerian Kesehatan Republik Indonesia. (2011). Modul Penggunaan Obat Rasional. Direktur Jenderal Bina Kefarmasian dan Alat Kesehatan. Jakarta.

Mayasari, Andrie M, \& Eka Kartika. (2015). Analysis of Potential Drug Interactions Injection of Insulin antidiabetic on prescribing Participants Askes Outpatients at $d r$. Soedarso Hospital Pontianak Period from April to June 2013.

Mozayani A. \& Raymon P. (2014). Interaksi Obat pedoman Klinis dan Forensik, Jakarta: EGC.

Murdiana. (2007). Evaluasi Penggunaan Obat Antihipertensi pada Pasien Diabetes Mellitus Tipe 2 di Rawat Jalan RS DR Muwardi Surakarta, Tesis Program Studi Farmasi Klinis, Sekolah Pasca Sarjana Universitas Gadjah Mada, Yogyakarta.

Mutmainnah. (2013). Hubungan Kadar Gula darah dengan Hipertensi Pada Pasien Diabetes Melitus Tipe 2 di RSUD Karangayar.

Perkumpulan Endokrinologi Indonesia (Perkeni). (2011). Konsensus Pengelolaan dan Pencegahan Diabets Melitus Tipe 2 di Indonesia. Jakarta.

Sukandar, Andrajati, Sigit, Adnyana, Setiadi, \& Kusnandar. (2013). ISO Farmakoterapi. Jakarta: ISFI Penerbitan.

Stockley. (2006). Stockley Drug Interactions. $6^{\text {th }}$ Edition by Ivan H. London : Stockley Pharmaceutical. 
Sweetman. (2009). Martindale : The Complete Drug Reference, Edisi 29. London : Pharmaceutical Press.

Tjay H.T. \& Rahardja K. (2010). Obat - Obat Penting , Khasiat, Penggunaan, dan Efek-Efek sampingnya. Jakarta: Elex Media Komputindo.

Triyanto E. (2014). Pelayanan Keperawatan Bagi Penderita Hipertensi Secara Terpadu. Yogyakarta: Graha Ilmu.

World Health Organization. (2011). Use of Glycated Haemoglobin (HbA1c) in the Diagnosis of Diabetes Mellitus. Abbreviated Report of a WHO Consultation. 